\title{
Globalization and growth in emerging markets and the New Economy ${ }^{\text {is }}$
}

\author{
Joseph E. Stiglitz* \\ Department of Economics, Columbia University, New York, NY 10027, USA
}

Keywords: Globalization; Growth; New Economy

(C) 2003 Published by Elsevier Inc. on behalf of Society for Policy Modeling.

\section{Introduction}

Not long ago, everyone was talking about the New Economy. Recent events - notably the global economic slowdown and a possible impending war - have crowded out discussions of the New Economy. To be sure, some of the rosy scenarios portrayed at the time - most notably, that the New Economy portended the end of the business cycle - seem curiously dated. Indeed, in terms of the gap between the economies potential and its actual performance, the current downturn is not only serious, it is prolonged. The current downturn is being widely described as the first global downturn of the new era of globalization, with Europe, Japan, and the US all in slumps, and with truly serious ramifications for many of the emerging markets of the world. A few countries, including China, India, Korea, and Vietnam have been spared, and, as I shall comment later, this is no accident. But even as the global slowdown has set in, productivity growth, especially in the US, has remained robust, a two edged sword: with the economy's output limited by aggregate demand, it has meant that unemployment has increased faster than it might otherwise.

Even in its hey-day, the New Economy raised a question: if the New Economy meant an increased pace of growth in the developed world, if the developing countries could not take advantage of the New Economy, then there would be increasing disparities in income. Rather than the convergence that was predicted

\footnotetext{
is Paper presented at the Annual Meetings of the American Economic Association, January 3, 2003.

* Tel.: +1-212-854-0334/1481; fax: +1-212-662-8474.

E-mail address: mk2110@columbia.edu (J.E. Stiglitz).
} 
by standard neoclassical theory, there would be divergence. These fears have, at least partially, been realized. In Latin America, the region that followed the precepts of the Washington consensus most closely (and indeed for which the Washington consensus was actually designed), growth was just over half of what it was in the pre-reform days, the fifties, sixties, and seventies, but most importantly, the gap between their Northern neighbor and themselves increased. In Africa, economic prospects were even more bleak.

Only in Asia, did matters look different. Some countries, like Korea, were not only embracing the New Economy, in some cases, they were actually leading it, with deeper penetration of some of the new technologies into their economies and societies even than in the West. The region showed that the New Economy could be a powerful force for reducing the divide between the advanced industrial countries and the developing world. As the World Bank increasingly emphasized in the late 1990s, what divided the developed from the less developed countries was not only a gap in resources, and especially capital, but also a gap in knowledge. The new technologies facilitating the closing of that gap.

But that raised a new question: what affected the differential ability of different countries to avail themselves of the new technology? Underlying the success were several ingredients: an ability and willingness to undertake risks; capital markets that were able and willing to supply funds to new enterprises; a trained and technologically savvy labor force; a close connection between universities and research centers and the business community. America had invented a new set of financial institutions, the venture capital funds, had first rate universities, and succeeded in importing some of the best scientific brains from around the world. But America's institutional arrangements were not the only ones that worked. The low unemployment facilitated young people taking risks: if the start up for which they worked went bankrupt, never worry - there was always another job in the offing. Some of the Scandinavian countries were equally successful, and their strong safety nets also facilitated risk taking.

The Asian countries had not followed the advice of Western experts, who told them to focus on primary education and which had discouraged them from adopting industrial policies aimed at closing the technology gap. In spite of their evident success, as recently as 1998, when the World Development Report focusing on knowledge argued that other countries should follow the lessons of East Asia, there was resistance.

But the policies that have been urged on the developing countries have impaired their ability to take advantage of the New Economy in other ways as well: they have increased the risk that these countries (and more particularly, firms within these countries) face, and they have pursued policies that have impaired the ability of capital markets to supply funds to new enterprises.

The old neoclassical theories ignored risk, ignored the role of financial institutions (capital simply flowed from where it was abundant to where it was scarce; there were no information problems that would impede this natural flow). That was why it predicted convergence (apart from problems that might arise from 
agglomeration economies and certain kinds of externalities). And that was why policies which were predicated on that model have so often turned out to be counterproductive.

This paper takes a closer look at globalization and growth. The faster communication of ideas should have lead to a faster rate of closing the knowledge gap; and the greater integration of capital markets should have lead to a faster rate of closing the resource gap. Indeed, globalization has, at the same time, been praised for holding out the potential for a new era of growth for developing countries at last closing the gap that separates them from the more developed countries.

But, as we have suggested, that has not occurred, and indeed, globalization has been vilified for increasing poverty, and even, in some circles, for impeding growth. There is an element of truth in both of these perspectives: globalization may bring enhanced growth, but need not, and it may lead to increased poverty, but need not. Some countries have, by and large, managed to take full advantage of globalization, getting the benefits while minimizing the downside risks, while others have not been so fortunate - they have partaken more of the costs than they have received of the benefits. The differing views on globalization are derived not only from these differing experiences, but also from the fact that within groups, globalization has impacted different groups differently: while some have benefited enormously, others have borne more of the costs. The hundreds of thousands of workers thrown out of job in East Asia in the midst of the East Asia crisis, and the millions more who saw their real wages plummet by $20 \%$ of more, and the multitude of small businesses that were forced into bankruptcy by the extremely high interest rates were innocent victims of globalization gone awry. They may see globalization differently from the financial interests that have earned returns as money flowed into the country, and earned still more money as they helped managed the restructuring of the economy.

East Asia itself provides the strongest testimony in favor of the positive effect of globalization on growth, and a counter to the view that globalization necessarily results in increased poverty. The East Asia miracle - the spectacular growth of the countries of East Asia which has not only raised GDP per capita by eightfold or more over the past thirty-five years, even taking into account the setback of the 1997 crisis, ${ }^{1}$ and raised hundreds of millions out of poverty ${ }^{2}$ — was largely based on globalization: ${ }^{3}$ export led growth, based in part on closing the technology gap between them and the more advanced industrial countries. ${ }^{4}$ Some countries, such

\footnotetext{
${ }^{1}$ Between 1960 and 1990, the East Asian countries grew more rapidly and more consistently than any other group of economies in the world. During the period, China, Hong Kong, Japan, Korea, Malaysia and Indonesia, Singapore and Taiwan grew an average of 5.5\% per capita real income growth annually (World Bank, 1994, p. 29).

2 Just in the decade between 1987 and 1998, the number of people living on less than US\$1 a day in the East Asia and Pacific region decreased from 417.5 to 278.3 million (World Bank, 2001, p. 23).

${ }^{3}$ See, e.g., Balassa (1991), Krueger (1995), and Stiglitz (1996).

4 The Krugman (1994) and Young (1994) debate about whether there was or was not an East Asia miracle is really beside the point. The facts are clear: per capita GDP increased enormously, poverty
} 
as China, also benefited enormously from foreign direct investment, while others, such as Korea, made little use of it. But key to their success was that they governed or regulated the globalization process, enabling them to benefit from the opportunities which it afforded, while not suffering as much from the downside risks. They took pragmatic policies, not influenced by the ideologies of the Washington consensus, neo-liberal doctrines. Thus, China showed that one could attract enormous amounts of foreign direct investment without having full capital market liberalization (indeed, it has been the most successful emerging market country in attracting foreign direct investment). ${ }^{5}$ In doing so, it avoided the ravages of the global financial tumult of 1997-1999. China, too, is now just bringing down a host of trade barriers (as it approaches joining the WTO). Much of the instability that has occurred in the past five years in East Asia was precisely because the affected countries succumbed prematurely to the pressures for capital market liberalization emanating from the US Treasury and the IMF, with the predicable, and predicted, results. ${ }^{6}$

A belief in the benefits of globalization, both higher growth and reduced poverty - if the countries would only put into place the kinds of policies and institutions which would allow them to take advantage of it - became part of the mantra of triumphant capitalism in the mid 1990s. Ironically, however, the policies and institutions which they advocated often departed markedly from those adopted in the one region in the world which had shown that globalization could work.

The global financial crisis and its aftermath brought home the darker side of globalization, and reminded those who had forgotten that capitalism, throughout its more than two hundred years history, has been plagued with wild fluctuations, that it is hardly a self-regulating system, and that, especially in its early days, there were many who seemed not to benefit from its fruits.

While the darker sides of unfettered globalization have led to a marked change of rhetoric - everyone now talks about the need for adequate safeguards - behind the tone of moderation the policy stances have changed less than the rhetoric. Those who believe in "almost unfettered globalization" for the emerging markets put forward two arguments. The first is that today, globalization is a matter of choice - unlike earlier eras where it was the result of gunboat diplomacy (Admiral Perry "opening up" Japan) and more open military intervention (the Opium War). Countries choose to globalize, and to adopt the institutions and practices that it seems to require, because it enhances their welfare. But those within developing countries see today's economic power as being the surrogate of yesterday's military power. The US, under its trade laws (so-called 301 and super-301 actions ${ }^{7}$ )

was reduced enormously; both changes were on an unprecedented scale. The gap in technology has been reduced enormously. Their only claim is that the changes themselves can be explained in terms of high levels of investment, including investments in technology. The methodology which they employ are particularly unrobust, but even if their conclusions about total factor productivity were true, it would not alter any of the analysis below.

${ }^{5}$ In 1997, China received 31\% of total FDI in the world (World Bank, 1999, p. 30).

${ }^{6}$ See, for instance, Furman and Stiglitz (1998) and Rodrik and Velasco (1999).

${ }^{7}$ See U.S. Department of State (2000). 
sets itself up as prosecutor, judge, and jury (without the defendant being able to mount an effective defense) on charges that the country has engaged in unfair trade practices. Countries are threatened with economic sanctions - and there are huge costs of not caving into US demands. Similarly, a country in the throws of an economic crisis, believing that it needs outside assistance, inevitably caves into IMF demands, as unrelated as those demands may be to the crisis itself, and even if those demands go beyond economics into politics, in violation of the Articles of Agreement of the IMF. ${ }^{8}$ It simply is not true that liberalization measures are undertaken voluntarily. The most that one can say is that those in power believe that they gain more from the liberalization measures than they would suffer from the consequences of not undertaking them.

A second related argument sometimes put forward is that countries that have partaken of globalization almost never reverse course; evidently, whatever the costs, the benefits exceed the costs. This argument is subject to the same criticism countries are keenly aware of the consequences of reversing course, of the pressure imposed, say, by the IMF and the United States. When Indonesia, hearing of the new thinking at the IMF about capital market liberalization, proposed rethinking the issue there, they were quickly batted down. Given their current position of dependence, they felt they had little choice but to follow the dictates of their new economic masters. But there are two further answers. Some countries have reversed course on the issue of capital market liberalization, though in order to avoid the wrath of the IMF and the US Treasury, they have done so with some subtlety, e.g., effectively imposing restrictions through the banking system. Finally, in many countries, even those that are "nominally" democratic, economic policy making, at least in the short run, is under the control of particular groups. When one says, "they" chose to keep their, say, their capital markets open, the "they" is likely to be the finance ministry, and the finance ministry may reflect more the interests and perspectives of the financial community than of society as a whole.

\subsection{Objectives of this paper}

While today it is recognized that globalization may have adverse effects on particular groups, in this essay, I want to set forth some of the reasons why globalization, when not managed well, may actually be adverse to overall economic growth, and the ability of countries to take advantage of the advances associated with the New Economy. Not just the poor may suffer. There are several channels through which the adverse effects may run. In presenting these adverse effects, one needs to keep in mind the objective of the analysis: Because I believe that globalization can be a powerful positive force, I believe that it is imperative that one must face up to the downside risks, and design programs, policies, and institutions that address these concerns. If this is done, globalization will not only be more acceptable,

\footnotetext{
${ }^{8}$ See Feldstein (1998).
} 
it will be more beneficial. The fact that, say, trade on average is beneficial to growth is of limited relevance to a particular country, if it sometimes is not, or it brings benefits on average, but enormous costs on particular groups. Countries worry that they will be off the regression line — and in the wrong direction.

\section{The multiple dimensions of globalization}

Globalization, as we have noted, has several distinct elements: (a) trade; (b) foreign direct investment; (c) short-term capital flows; (d) knowledge; and (e) movements of labor. Over the past few years, there is an emerging consensus on the relative merits of these various aspects of globalization:

\subsection{Knowledge}

At the top of the list is globalization of knowledge, the free flow of ideas that has followed the lowering of communication costs and the closer integration of societies. The transfer of that knowledge, which globalization has facilitated, is likely to prove one of the strongest forces for growth in emerging markets in coming decades. ${ }^{9}$ This globalization of knowledge not only entails technical knowledge, but ideas which transform societies - ideas like democracy and markets - and knowledge which forms the basis not only of the adoption of policies which serve to enhance growth but also of institutions. To be sure, there is here, as elsewhere, the possibility of a darker side: the adoption of institutions without appropriate adaptations, leading to dysfunctional behaviors. This is especially the case when outsiders, such as the IMF, attempt to impose institutions and legal frameworks (such as those relating to bankruptcy) on a country without adequate sensitivity to local conditions and social norms. ${ }^{10}$

\subsection{Trade}

A wealth of cross-country studies ${ }^{11}$ suggests a positive relationship between trade and growth, though some more studies has cast some doubt (see Easterly, 1993; Rodrik \& Rodriguez, 1999). Standard theory has argued that countries benefit from removing their own barriers, even if trading partners do not reciprocate. This "unilateral disarmament" approach to trade liberalization, while it has been extensively pushed on developing countries, has been resisted in their own approaches to trade liberalization by the very countries, such as the United States

\footnotetext{
${ }^{9}$ See the 1998/1999 World Development Report (World Bank, 1999).

${ }^{10}$ There have also been concerns about adverse effects on culture - that some cultures may not withstand the onslaught of homogenization. Here, as elsewhere, the issue of pacing can be critical. The encounter between differing cultures can lead to the strengthening of traditional cultures, if there is time for adaptation (including the creation of new institutional arrangements for the transmission of culture).

${ }^{11}$ Sachs and Warner (1999).
} 
which have pushed it most strongly. They have typically refused to lower domestic trade barriers unless they win parallel concessions from their trading partners. To be sure, this is sometimes viewed as necessary to get the broad political backing for trade liberalization - an aspect, however, which is at the same time ignored by the international financial institutions as they make demands for reforms on their developing country clientele, even as they praise them for adopting democratic processes. But even when it is the case that a particular small country might benefit from trade liberalization on its own, there can be terms of trade effects from broad patterns of trade liberalization, and the unfair trade agenda - liberalization directed at lowering global impediments to goods which are the developed countries' comparative advantage - has resulted in sub-Saharan Africa, the poorest region in the world, actually being worse off at the end of the last round of trade liberalization. ${ }^{12}$

\subsection{Labor}

The least studied, and discussed, aspect of globalization are labor flows. It is indicative of the extent to which the globalization agenda has been controlled by financial interests that while the important of global financial movements for global efficiency has been continually stressed, hardly a word has been mentioned about labor flows. But global economic efficiency is enhanced just as much by the movement of different types of labor, from areas where there productivity is low to areas where there productivity is high: indeed given the markedly larger differentials in returns to labor than in returns to capital, the gains from such movements would presumably be all the greater. Yet the potential adverse consequences of large movements of labor (at least to particular groups within, say, the more developed countries, to which labor is likely to flow) are sufficiently widely recognized that no country has proposed the unfettered movement of labor. The fact that the globalization agenda has focused on the free movement of capital, and virtually ignored the movement of labor, reflects in part who is controlling that agenda.

While these movements of labor might simultaneously increase GDP in the more developed countries and lower incomes of certain groups within those countries, they have similarly ambiguous effects on the developing world. The remittances of migrant labor have been an important source of income in several developing countries, and, in a few instances, the technology and entrepreneurship of the "diasporas," the migrants who have succeeded abroad and returned to the home country to establish new enterprise, has played a critical role. At the same time, there are some instances where the outflow of young, skilled workers has bled a country of an essential input for its economic growth. ${ }^{13}$

\footnotetext{
${ }^{12}$ See Stiglitz (1999) and studies cited there.

${ }^{13}$ A factor could be relatively scarce and yet have a lower private return (but a higher social return) whenever there is a significant disparity between private and social returns. New growth theories
} 


\subsection{Foreign direct investment}

Movements of capital take several different forms: direct investment by foreigners, for instance, in constructing factories; and portfolio investment. Portfolio investment can either take the form of short-term capital flows (short-term lending) or long-term flows, e.g., long-term bonds. There are markedly different consequences of these different forms of capital flow. Foreign direct investment is widely praised for, bringing not only capital, but access to foreign markets, technology, and human capital. Moreover, it suffers from less cyclical volatility than does portfolio capital. But as we shall see, even foreign direct investment does not always yield the promised results.

\subsection{Capital market liberalization}

Capital market liberalization - allowing the freer flow of short-term capital around the world — has been the most controversial aspect of globalization, though this controversy is now subsiding. Just as the East Asian financial crisis was beginning, the IMF went to its annual meetings in Hong Kong asking for a change in charter, to allow it in effect to push capital market liberalization on the countries of the world. It did this without evidence that such liberalization would improve growth, or the economy or the lives of the people - and with a wealth of evidence suggesting that it would contribute to economic instability with especially adverse consequences on the poor in emerging markets, most of which did not have adequate institutions to manage the resulting risk or deal with the consequences (including adequate safety nets). Today, senior officials at the IMF recognize the dangers of capital market liberalization, ${ }^{14}$ though it is not clear that policies being pushed on developing countries have fully reflected this new thinking.

\section{How globalization, as currently managed, adversely affects growth in developing countries}

There are eight broad, and often intertwining, channels through globalization can exercise adverse effects on growth. It affects - and not always positively — the pace of job creation. It affects - almost always adversely - the risks a country faces. While uncontrolled short-term capital flows have played such an important role in globalization in the 1990s, these capital flows do not provide

\footnotetext{
have emphasized the importance of agglomeration economies; migration may make it difficult for an "agglomeration" of skilled workers of sufficient magnitude to allow the economy to take-off. There may, under these circumstances, multiple equilibrium; easy out-migration of skilled workers may make it difficult for a country to move out of the low-level equilibrium trap. See, e.g., Hoff and Stiglitz (1993) and the studies cited there.

${ }^{14}$ See, e.g., Fischer (2001) and Mussa (2000).
} 
the funds with which to finance growth but do increase risk; they force countries to put aside funds with opportunity costs into low yielding reserves, and lead to adverse macro-economic consequences, from high exchange rates to high interest rates required for sterilization. In other countries, globalization has meant massive capital flights, depriving countries of the capital they need to grow. Openness, more generally, has reduced the scope for monetary policy, leading to more economic instability; and the loss of independent national financial institutions often puts domestic firms at a marked disadvantage in raising capital.

But some of the most important, and adverse effects, relate to how globalization affects the political and social "equilibrium," in ways which may not always be positive for long-term growth.

\subsection{Job creation}

At the core of growth, and poverty reduction, is job creation. While this may seem a truism, it is a fact which is not always fully taken on board. Jobs are not created automatically or instantaneously. No one today believes in Say's Law, that an increase in the supply of labor automatically leads to an increase in the demand for labor. Unemployment is not a phantasm. This is important, because unless one understands what leads to job creation, and what leads to unemployment, one cannot be sure of whether a particular policy will increase or decrease growth, increase or decrease poverty. The standard theory of comparative advantage argues that eliminating trade barriers is desirable, because it results in resources moving from low productivity uses to high productivity uses. That increases GDP, and while there may be distributional consequences in principle everyone could be made better off. To be sure, the requisite redistributions are almost never made, with consequences for social and political stability - and thus economic growth — that I turn to in Section 3.8 below.

But all too often, what seems to happen is that old jobs in the protected industries are eliminated before new jobs are created. Resources do not move from low productivity uses to high productivity uses, but from low productivity uses to zero productivity unemployment. Doing so increases poverty and decreases GDP.

Job creation depends on a number of factors, including the overall business environment, risk, and the cost of capital. Globalization, in the way it has been practiced, has had a number of adverse effects on the overall business climate, making job creation all the more difficult. In the next two sections, I shall discuss how it has adversely affected risk and "social capital." Most importantly, one has to recognize that job creation requires investment. To be sure, advocates of trade liberalization often accompany these measures with exhortations concerning accompanying changes that would make it more attractive to invest in the country. But in fact, these changes are not made prior to the liberalization, and all too often, the liberalization package overall actually leads to changes which make it less, not more, attractive to invest. In particular, "adjustment" packages including trade liberalization often also are accompanied by monetary tightening, raising interest 
rates to levels which would make it unattractive to invest even in a country like the United States with a good business climate. And they are typically not accompanied by measures to strengthen the ability of the financial system to make loans to new enterprises. Indeed, the high interest rates often induce the few financial institutions to focus on lending to the government - why undertake risky lending, with all the problems of screening, monitoring, and enforcement, if one can get a sure return from the government of $30,50 \%$ or more.

\subsection{Risk}

Globalization, especially done the wrong way, can increase risk; and increased risk can have an adverse effect on economic growth. ${ }^{15}$ Let us consider each part of the argument, and the way in which the various forms of globalization increase risk.

I have already referred to the risk imposed by capital market liberalization. The surges of capital, first into the country, and then out, impose tremendous costs, regardless of the exchange rate regime. Under flexible exchange rates, for instance, these surges are likely to lead to large changes in exchange rates, imposing huge risks on every aspect of society. But I am concerned not just with the overall welfare costs, but the adverse effects of growth. Firms facing more highly volatile prices of inputs and outputs will demand a compensating risk premium - with an adverse effect on investment and growth. The real irony is that capital market liberalization was sold to East Asia on the basis that it would contribute to their stability - after all, with savings rates of $30 \%$ or more, they hardly needed an influx of more capital. The point was that in the event of an economic slowdown in their country, they could turn to international capital markets to sustain their economy. But such arguments, whatever the theoretical merits, ran counter to experience, both before and during the crisis: short-term capital is a fair weather friend; these flows proved themselves to be pro-cyclical, as they had earlier shown themselves in Latin America. ${ }^{16}$

Capital market liberalization is also systematically related to financial and currency crises, ${ }^{17}$ and such crises - which can be viewed as extreme forms of instability - have enormous costs. Research ${ }^{18}$ has shown that such instability has huge costs in terms of economic growth, and for obvious reasons. Often such crises devastate the financial system, and without outside sources of finance, enterprises must rely on self-generated funds, slowing growth.

The anticipation of risk itself has adverse effects, not only through the higher risk premium that investors demand. Risk averse firms, particularly worried about

\footnotetext{
${ }^{15}$ It has long been known that in the absence of good risk markets, trade liberalization can actually lead to a pareto inferior equilibrium. See, e.g., Newbery and Stiglitz (1984). And indeed, the switch from quotas to tariffs, a standard part of the globalization agenda, can be shown under many circumstances to increase the risks faced by developing countries. See Footnote 17.

${ }^{16}$ See Easterly et al. (1997) and Hausmann and Rojas-Suarez (1996).

${ }^{17}$ See Demirgüç-Kunt and Detragiache (1998) and Rodrik (1998).

18 Caprio and Summers (1996).
} 
the risk of bankruptcy, ${ }^{19}$ will limit their indebtedness, but this in turn will limit the pace of their expansion. Korea's (and much of the rest of East Asia's) success was based on a high debt policy. Thus, the risk attendant upon capital market liberalization inevitably will slow growth, all the more so because of the way that the IMF typically forces countries to respond, by raising interest rates to exorbitant levels. Innocent firms, that have avoided foreign indebtedness, or have prudently covered their foreign exchange exposure, typically cannot buy insurance against the volatility of interest rates; they can only respond to the new globalized environment by cutting back on their indebtedness. To be sure, larger firms may eventually have access to securities markets - which have marked risk advantages over debt in any case; but even in developed countries, relatively little new capital is raised in equity markets, ${ }^{20}$ and it will take some time for the appropriate legal frameworks to be established in the best of the countries. ${ }^{21}$ And a few of the very large firms can tap into globalized equity markets in the US and Europe - but this can hardly be the basis of broad growth.

Moving up the chain, risks that firms face are translated into risks that the financial institutions that lend firms money face, and thus risk increases the spreads which they demand, the constraints which they impose on lending, and so forth. All of this adversely affects the creation of jobs and growth.

Governments too need to respond to the risk imposed by capital market liberalization, especially capital market liberalization. And they do this by putting aside more reserves. Indeed, it has become conventional wisdom that countries' reserves should at least equal their short-term outstanding debts. But holding reserves is costly, and has adverse effects on growth. To see why, assume a firm in a small African country borrows US\$100 million from an American bank, paying 18\% interest. Prudential policy on the part of the African country would require that it would add US $\$ 100$ million to reserves. Typically reserves are held in US treasury bills. In effect, the country is borrowing from the United States at 18\%. The country has no more resources available for investing. It is clear why the United States might find this activity attractive: American banks may have made a tidy profit, and America as a whole gains US\$14 million a year. But it is hard to see how this allows the country to grow faster.

Capital market liberalization is not the only aspect of "globalization" that often is accompanied by an increase in risk. Even trade liberalization can lead to an increase in risk, given the huge volatility of commodity prices. Again, an increase

\footnotetext{
${ }^{19}$ There is considerable evidence that, even in developed countries, with good risk markets (which allow the transfer, divesting, and diversification of risk) firms act in averse manner (see Greenwald \& Stiglitz, 1990 and Stiglitz, 1999). In developing countries, the arguments are even more compelling. The explanations for why this should be so are summarized in Greenwald and Stiglitz (1990).

${ }^{20}$ See Mayer and Alexander (1990).

${ }^{21}$ Recent work has, moreover, cast considerable doubt on research showing that countries with deeper equity markets grow faster. It turns out that this result is not true when growth is measured in the country's own real terms; earlier results seem to suggest only that equity markets have impacts on exchange rate movements.
} 
in risk, for whatever reason, increases the cost of capital, adversely affecting job and enterprise creation. ${ }^{22}$ Some government interventions may be able to mitigate the consequences. ${ }^{23}$

\subsection{Why capital flows may not translate into more growth}

The standard line on development is the developing countries are short of capital; an inflow of capital therefore will enable them to grow faster. Sometimes that is true, but sometimes it is not, and my objective here is to help delineate the circumstances in which it is true. We distinguished earlier between different forms of capital flows, e.g., foreign direct investment versus other flows; and within the other flows, we can distinguish between short-term bank loans, say, and longer term portfolio flows. We have already noted that there is little evidence that capital market liberalization, aimed at facilitating short-term flows, leads to faster economic growth, and some reasons to believe that it might actually inhibit economic growth. We have already seen several of these reasons: one cannot construct new jobs and enterprises with money that can flow in and out overnight. Liberalization brings with it risk, increasing the effective cost of capital. If countries have to put aside money into reserve to offset the risk, there is a real opportunity cost - funds can be thought of as effectively diverted from other, high yielding forms of investment.

There are still other effects which have recently been emphasized: an inflow of financial (or portfolio) capital can lead to an appreciation of the currency, unmatched by additional real investment, making it less attractive to make real investments - a form of Dutch disease. While standard doctrines hold that the resulting trade deficits are of no concern, that they are in fact sustainable - after all, investors would only put money into a country if the returns exceeded the opportunity cost of capital - in practice that is not the case, and is not perceived to be the case - trade deficits give rise to anxiety even if they are "caused" by investment opportunities. And such anxieties may, accordingly, have an adverse effect on job creation and growth.

Thailand illustrates an even worse scenario. The influx of "capital," unmatched by increased imports (e.g., as a result of an increase in demand for capital goods) would have led to inflation in an economy already running at close to full employment; to avoid inflation, the influx had to be sterilized, leading to high interest rates (inducing even more influx of capital). The effect was that foreign investment in empty office buildings crowded out almost surely more productive domestic investments, with clearly adverse effects on growth. ${ }^{24}$

\footnotetext{
${ }^{22}$ See Easterly and Kraay (2000).

${ }^{23}$ See Dasgupta and Stiglitz (1985).

${ }^{24}$ The alternative of reduced public expenditures would have been equally deleterious: in that case, private investments in empty office buildings would have, in effect, displaced much needed investments in education and infrastructure. A third alternative, increasing taxes, may or may not have been effective, but in any case was viewed to be politically feasible, especially since the government was already running fiscal surpluses.
} 


\subsection{Facilitating capital flight}

If an influx of capital, under certain circumstances, may have adverse effects on the economy, there is an even stronger presumption that the rapid outflow of capital from a country is deleterious, and especially so if the outflow is "capital flight," that is capital from domestic investors. Globalization - as it has been managed — has facilitated such outflows.

Capital market liberalization was supposed to make it more attractive for capital to come into a country - though even without capital market liberalization, governments can give assurances about the repatriation of funds, as China has amply demonstrated. Earlier, we explained how capital market liberalization had increased risk. But there is another adverse consequence of capital market liberalization in some countries: it facilitates the flight of capital. In these circumstances, rather than leading to a net flow of capital into a country, as promised, it has led to a net outflow. Both Africa ${ }^{25}$ and Russia, natural resource rich areas, have been plagued with problems of capital outflows. The case of Russia is telling: partially under pressure from the IMF and the US Treasury, Russia engaged in rapid privatization; the loans-for-share privatization, in which a few oligarchs picked up valuable state assets at a fraction of the value, in particular, lacked political legitimacy. With capital market liberalization, these oligarchs were, effectively, given a choice: keep your money in Russia, a country experiencing a depression, with the possibility - even likelihood - that a future government will question the legitimacy of the privatization; or take your money abroad, invest it in the booming US stock market, squirreling it away where it cannot be attacked by future governments. Capital market liberalization resulted in a Nash equilibrium in which it paid each to withdraw his money; and with that withdrawal, the economy's downward spiral was perpetuated. It is conceivable that with capital market liberalization, there would have been an equilibrium in which it paid each to invest his money in productive enterprises and job creation.

Sudden capital outflows - which marked the crises in Mexico and in Indonesia - are particularly harmful. They typically lead to a marked decrease in the exchange rate, which in turn has marked adverse effects on those who have uncovered positions with foreign denominated debt. To be sure, one might lecture that firms should not have such exposures, and one might argue that risk adverse firms only would have such exposures (and risk averse creditors would have allowed such exposures) only if they believed that there was a significant chance of an IMF or government bail-out, a belief which recent history may have served to reinforce. But the fact is that there are typically large numbers of firms who do have exposures, and even with the bail-outs there are large real wealth effects, the consequence of which is a contraction in production, a

\footnotetext{
${ }^{25}$ See Collier and Gunning (1999).
} 
disruption of the financial system, and often widespread bankruptcy and corporate distress. ${ }^{26,27}$

\subsection{Loss of independence of monetary policy}

Surrendering to unfettered globalization through capital market liberalization also entails a loss of control over monetary policy and/or exchange rate policy, and this loss of control can be very costly to economic growth, a fact brought home forcefully in the most recent global financial crisis. Malaysia's capital controls allowed it to maintain exchange rate stability at lower interest rates. The lower interest rates were not only good for economic growth - the economy was facing a major economic downturn, and the higher investment associated with lower interest rates was good for both the short and long-term - but placed less of a burden on expansionary fiscal policy, thus leaving in the aftermath of the crisis less of legacy of government debt (which could have an adverse effect on future growth). Moreover, the lower interest rates meant that fewer firms were forced into distress, a particular concern given the heavy level of indebtedness. Such distress too has a negative effect on growth, both because firms that survive still go through a period of lower investment, and because many firms do not survive, at an enormous cost in terms of a loss of informational and organizational capital. Moreover, the costs imposed on the banking system, and ultimately on the government, in addressing this distress were lower, again leaving less of a legacy of debt, with its adverse effects on future growth.

\subsection{Loss of national financial institutions}

Globalization has also been associated with opening up financial services markets. Banks in developing countries are often at a marked disadvantage in

${ }^{26}$ See Greenwald (1998) and Greenwald and Stiglitz (1993). These adverse effects can happen even if the country, on net, is not in debt, simply because the losses of the debtors has a more adverse effect on production (aggregate supply) than the gains of the creditors. Most developing countries are, however, net debtors, making the adverse effects all the greater.

${ }^{27}$ At first blush, this and the previous section might seem to contradict each other. There, I argued that an appreciation of a currency was bad for a country; here I seem to be arguing that a depreciation is harmful. The two perspectives are, however, consistent. What is at issue is dynamics. In the previous section, I focused on the level of the exchange rate, here I am focusing on sudden changes in the exchange rate. Slow and steady decreases in the exchange rate do not typically have the adverse effects of crises, because firms have time to adjust; firms are not thrown into bankruptcy; there are a variety of ways in which the risks of small changes in exchange rates can be mitigated.

The disruption in the corporate sector is reflected in a disruption in the financial sector, resulting in the unavailability of credit. These disruptions largely undid the positive effects of devaluation on exports: export firms could not get the credit they needed to respond to the potential increases in demand, and the increased likelihood of bankruptcy made firms say, in Indonesia, unreliable suppliers, so that demand did not increase any where as much as would have been predicted on the basis of the magnitude of the exchange rate change. 
competing with large international firms. While the evidence on economies of scale and scope is not always clear, it is clear that banks have defended their mega-mergers on the grounds that such economies are significant, and that such gains outweigh the losses from reduced competition, e.g., in the market for small and medium size business loans (where competition is often, in any case, very limited). Even if there is a slight grain of validity to these claims, it means that a small bank in Ethiopia has little chance in competing against a behemoth like Citibank. Certainly, in the absence of good deposit insurance, most depositors would have greater trust in Citibank, and hence the domestic bank would have to pay significantly higher interest rates to attract funds.

The adverse effects on growth are, however, more related to the lending side: where do the funds flow? In the United States, there has long been a concern that national banks would divert funds to the large money centers and the enterprises that operate there, and this provided part of the restrictions on nation wide (and even, in many places, state-wide) banking that were only eliminated in 1995.

Argentina has experienced the consequences of the replacement of national banks with global banks: while its banking system has survived the global economic fluctuations, the banking system has not done what banks are supposed to do: provide credit for small and medium size enterprises. The lack of credit no doubt has been an important factor contributing to that country's persistent double-digit unemployment rates.

Moreover, foreign banks may be less subject to window guidance than domestic banks, and thus the ability of the monetary authorities to control the economy to ensure full employment with low inflation - may be reduced. This may be especially important in open developing countries, where price (interest based) interventions may be less effective, and where there may be more instrument uncertainty, e.g., the link between open market operations, tightness as measured by interbank rates, and lending rates and credit availability may be less reliable.

\subsection{Globalization and the domestic political equilibrium}

One of the great ironies is that developing countries, like the Congo and Nigeria, with a wealth of natural resources, have not fared well: evidently wealth isn't everything. Rather than wealth creation, there is constant fighting over the division of rents. Globalization has played a key role in this destructive civil strife. The most obvious cases involve the diamonds which have fueled the conflict in Sierra Leone. But the problem, in less dramatic form, is more pervasive. Bribes to win concessions - or even to obtain protection for investment - undermines democratic political processes; the resulting corruption almost inevitably has adverse effects on the investment climate and thereby economic growth. ${ }^{28}$ The banana republics were effectively controlled by corporate interests. These powers virtually

\footnotetext{
${ }^{28}$ See Haggard and Kaufman (1992) and World Bank (WDR, 1997).
} 
replaced governments at will. Today, those same corporate interests often exert influence through the offices of the international financial institutions ${ }^{29}$ and national government's trade representatives.

There is another, related channel through which globalization as presently practiced may have adverse effects. We have seen how capital market liberalization often leads to crises. Crises, in turn, lead to IMF programs. When the IMF enters a country, it often effectively dictates terms, undermining fragile political consensus. Moreover, reforms, when undertaken at the dictation of outsiders, are not political sustainable. They cannot withstand the vicissitudes of the political process. Investors - both domestic and foreign — know this; there will be a lack of long-term credibility. In this perspective, it is not an accident that the countries with the fastest economic growth (such as China and Botswana) have not had IMF programs.

\subsection{Globalization and social capital}

Indonesia provided a dramatic illustration of the adverse consequences of political and social turmoil, an indirect consequence of globalization. Capital market liberalization had led to crisis; excessively contractionary monetary and fiscal policies imposed by the IMF had led to a depression, exacerbated by a perverse IMF led strategy for addressing the weaknesses in the financial institution; ${ }^{30}$ and finally, the cutting of food and fuel subsidies for the poor, as incomes plummet and unemployment soared, had the predictable consequence of inducing political and social turmoil, in a country with a history of ethnic fractionation. This in turn led to further flight of capital — and human capital — further deteriorating the economy and making a recovery all the more difficult. While there are many factors contributing to this dismal tale, globalization and the way it is managed by the international financial institutions, surely is at the center.

Indonesia illustrates the extremes; but more generally, the risks and social disruption often associated with globalization - in the way that it has been managed — undermines social cohesion, social consensus. And this in turn adversely affects economic growth. Market economies require that contracts be lived up to; legal systems are central, but they provide only a backdrop: most contracts are not enforced by legal action, but are self-enforcing, e.g., by reputation mechanisms. Economic

\footnotetext{
${ }^{29}$ The most widely cited recent example was in the crisis in Korea, where the IMF forced Korea to accelerate reducing tariffs on certain imports from Japan in order to receive assistance, even though such tariffs had absolutely nothing to do with on set of the crisis or its resolution.

${ }^{30}$ In the case of Indonesia, the Fund closed 16 banks, announced more were to be closed, but that depositors would not be insured. The resulting run in the private banking system was predictable. But even more generally, IMF simply did not understand the fallacy of composition, among the first lessons in economics: there is a fundamental difference in how one should address weaknesses in a single bank, in a well functioning financial system, and systemic distress; then, rigorous enforcement of capital adequacy standards can be counterproductive, as each bank responds by cutting back lending, leading to a systemic lack of liquidity, increased corporate distress, further deepening the recession or depression.
} 
disruption, associated with globalization (e.g., capital market liberalization) undermines the effectiveness of these reputation mechanisms: at high effective interest rates, the value of "cheating" can exceed the value of complying with the contract.

There are a myriad of ways in which the social contract can be broken. Traditional societies have traditional safety nets. Under rapid transformation, these traditional safety nets may not be able to cope with the burdens that are thrust upon, and the safety nets themselves may erode. Traditional employer employee relations - in which employers do not lay off workers even when the firm is going through a bad time - are challenged by the demands of globalization, especially under the aegis of the IMF, which insists on rapid restructuring, mercilessly laying off workers when they are not needed. There may be short run gains, but the erosion of social capital — the belief that the system is "fair" — can have tremendous long-term costs. This is especially the case when the government has not yet set up an adequate public safety net, and/or when funds for basic social needs are limited, yet the government (again under IMF programs) somehow finds funds for massive bail-outs of corporations or the financial sector. In Mexico, while billions were being spent in addressing the problems of the banks - problems which themselves were widely viewed as having originated in the earlier privatization of the banking system, a misguided privatization which itself was pushed by the same forces that were pushing for a cutback in social expenditures, the government was claiming it did not have enough money for education, and had to raise tuition. The point about this (and other examples) is that what matters is perceptions, beliefs that certain groups (particularly the poor and powerless) have not been treated fairly. These perceptions are enhanced by the manner in which the policies (e.g., the reforms under IMF programs) are enacted, which are viewed as being imposed by outsiders, often reflecting international corporate and financial interests. The policies are not explained; the true incidence — who benefits and who loses — is not discussed, the negotiations are typically conducted in secret, the agreements themselves often not even fully disclosed, all of which leads to the impression that there is something to hide.

There are other ways that social capital can be undermined. A country's identity is defined by its culture; globalization often brings a clash between traditional cultures and the new cultures which it brings, with traditional cultures often faring the worst. Were there time for adaptation, the traditional culture might be able to evolve, a variant of the traditional culture emerging which helps reinforce civic identity. But when globalization proceeds apace, nothing may develop to fill the gap.

There are still other channels through which globalization - in the way that is has been managed - adversely affects social capital. We noted earlier how trade liberalization accompanied by high interest rates can lead to increased unemployment; increased unemployment, particularly if persistent, itself can be associated with increased violence, as we have seen in Latin America.

Whatever the mechanism by which social capital is eroded, firms, recognizing the erosion of social capital, and its consequences, find it less attractive to invest in 
the country. And the actions which they take to mitigate the effects may similarly have adverse effects on economic growth. In Russia, one interpretation of the massive arrears and the move to barter was to "tie" good workers to their firm, replacing the "bonds" that had previously been provided by implicit contracts.

\section{Concluding comments}

Countries that have managed the globalization process well have shown that globalization can be a powerful force for economic growth. But more commonly, globalization - under the auspices of the IMF — has not been so well managed. It is well known that not everyone benefits. There are losers. Even poverty can increase. Here, however, I have gone further: I have explained why globalization, when not well managed, may even adversely affect growth. Average incomes, not just the incomes of the poor, may suffer. I have identified eight channels through which these adverse effects are experienced.

It should be clear that globalization affects growth in different countries differently. Indeed, as we have seen, some of the channels by which developing countries are adversely affected actually confer benefits on the United States and other developed countries. Developing countries are forced, in effect, to hold large reserves in dollars or euros, providing low or zero interest loans from developing countries to developed countries. International financial arrangements which increase risk, and force the developing countries to bear risk (e.g., associated with interest rate and exchange rate changes) increase the incomes of those who have a comparative advantage in absorbing risk - the developed countries - at the expense of those who have a comparative disadvantage — the developing countries.

The lesson is simple: not to walk away from globalization, not to put on blinders to these costs, costs which are not just potential, but have actually been experienced by many countries. Only if one is aware of the downside, can one design policies to mitigate these risks, thus making it more likely that globalization will in fact live up to the claims that its ardent advocates have put forward.

\section{Acknowledgments}

Financial support from the Ford, Mott, MacArthur and Rockefeller Foundations is gratefully acknowledged. Research assistantship from Niny Khor is gratefully acknowledged.

\section{References}

Balassa, B. (1991). Economic policies in the Pacific area developing countries. New York: New York University Press. 
Caprio, G., \& Summers, L. (1996). Financial reform: Beyond laissez faire. In D. Papadimitriou (Ed.), Stability of the financial system. New York: Macmillan.

Collier, P., \& Gunning, J. W. (1999). Explaining African economic performance. Journal of Economic Literature, 37(1), 64-111.

Dasgupta, P., \& Stiglitz, J. (1985). Learning by doing, market structure, and industrial and trade policies. Oxford Economic Papers, 40(2), 246-268.

Demirgüç-Kunt, A., \& Detragiache, E. (1998, April 20-21). Financial liberalization and financial fragility. Paper presented to the Annual World Bank Conference on Development Economics, Washington, DC.

Easterly, W. (1993). Good policy or good luck? Country growth performance and temporary shocks. National Bureau of Economic Research Working Paper No. 4474.

Easterly, W., \& Kraay, A. (2000, November). Small states, small problems? Income, growth, and volatility in small states. World Development, 28(11), 2013-2027.

Easterly, W., Loayza, N., \& Montiel, P. (1997, November). Has Latin America's post-reform growth been disappointing? Journal of International Economics, 43(3/4), 287-311.

Feldstein, M. (1998, March-April). Refocusing the IMF. Foreign Affairs, 77(2), 20-33.

Fischer, S. (2001, January 6). Exchange rate regimes: Is the bipolar view correct? Delivered at the Meetings of the American Economic Association, New Orleans.

Furman, J., \& Stiglitz, J. (1998, September 3). Economic crises: Evidence and insights from East Asia (Vol. 2, pp. 1-114). Brookings papers on economic activity. Presented at Brooking Panel on Economic Activity, Washington, DC.

Greenwald, B. (1998, April 20-21). International adjustments in the face of imperfect financial markets. Paper prepared for the Annual World Bank Conference on Development Economics, Washington, DC.

Greenwald, B., \& Stiglitz J. (1990, May). Asymmetric information and the new theory of the firm: Financial constraints and risk behavior. American Economic Review, 80(2), 160-165. NBER Working Paper No. 3359.

Greenwald, B., \& Stiglitz, J. (1993, February). Financial market imperfections and business cycles. Quarterly Journal of Economics, 108(1), 77-114.

Haggard, P., \& Kaufman, R. (1992). Economic adjustment and the prospects for democracy. In P. Haggard \& R. Kaufman (Eds.), The politics of economic adjustment: International constraints, distributive conflicts, and the state (pp. 319-350). Princeton: Princeton University Press.

Hausmann, R., \& Rojas-Suarez, L. (Eds.). (1996). Volatile capital flows: Taming their impact on Latin America. Washington, DC: Inter-American Development Bank; distributed by Johns Hopkins University Press, Baltimore.

Hoff, K., \& Stiglitz, J. (1993). Consequences of limited risk markets and imperfect information for the design of taxes and transfers: An overview. In K. Hoff, A. Braverman, \& J. Stiglitz (Eds.), The economics of rural organization: Theory, practice, and policy. Oxford: Oxford University Press for the World Bank.

Krueger, A. (1995). The role of trade in growth and development: Theory and lessons from experience. In R. G. Enzo Grilli \& J. Riedel (Eds.), Sustaining export-priented development: Ideas from East Asia (pp. 1-30). Trade and development series. New York: Cambridge University Press.

Krugman, P. (1994, November-December). The myth of Asia's miracle. Foreign Affairs, 73(6), 62-78.

Mayer, C., \& Alexander, I. (1990, December). Banks and securities markets: Corporate financing in Germany and the United Kingdom. Journal of the Japanese and International Economy, 4(4), $450-475$.

Mussa, M. (2000, August 25). Factors driving global economic integration. Presented in Jackson Hole, Wyoming at a Symposium sponsored by the Federal Reserve Bank of Kansas City on Global Opportunities and Challenges.

Newbery, D., \& Stiglitz, J. (1984). Pareto inferior trade. Review of Economic Studies, 51(1), 1-12.

Rodrik, D. (1998, May). Who needs capital-account convertibility? Essays in International Finance, 207, 55-65. Princeton. 
Rodrik, D., \& Rodriguez, A. (1999). Trade policy and economic growth: A sceptic's guide to the cross-national evidence. Centre for Economic Policy Research Discussion Paper: 2143.

Rodrik, D., \& Velasco, A. (1999). Short-term capital flows. Paper prepared for the 1999 ABCDE Conference at the World Bank.

Sachs, J., \& Warner, A. (1999, June). The big push natural resource booms and growth. Journal of Development Economics, 59(1), 43-76.

Stiglitz, J. (1996, August). Some lessons from the East Asian miracle. World Bank Research Observer, 11(2), 151-77 (Reprinted as "Algunas ensenanzas del milagro del Este Asiatico" (with English summary) Desarrollo Economico, 37(147), 323-349, 1997, October-December).

Stiglitz, J. (1999). Trade and the developing world: A new agenda. Current History, 98(631), 387-393. United States Department of State. (2000, May 1). Monitoring and enforcing trade laws and agreements. Fact sheet, released by the office of the U.S. trade representative, executive office of the President, Washington, DC.

World Bank. (1994). The East Asian miracle. Oxford: Oxford University Press for the World Bank.

World Bank. (1997). World development report: The state in a changing world. Oxford: Oxford University Press for the World Bank.

World Bank. (1999). World development report: Knowledge for development. Oxford: Oxford University Press for the World Bank.

World Bank. (2001). World development report: Attacking poverty. Oxford: Oxford University Press for the World Bank.

Young, A. (1994). Lessons from the East Asian NICS: A contrarian view. European Economic Review, 38(3/4), 964-973. 